\title{
ESTADO SOCIOAMBIENTAL DE DIREITO E O PRINCÍPIO DA SOLIDARIEDADE COMO SEU MARCO JURÍDICO-CONSTITUCIONAL
}

\author{
TIAGO FENSTERSEIFER ${ }^{*}$
}

\begin{abstract}
RESUMO: O presente estudo analisa o surgimento do modelo de Estado Socioambiental de Direito, sedimentado sob o marco jurídico-constitucional do princípio da solidariedade, caracterizando os deveres de proteção ambiental conferidos ao Estado, bem como os deveres fundamentais ambientais atribuídos aos atores privados.

PALAVRAS-CHAVE: Estado Socioambiental de Direito; Justiça Ambiental; Direito Fundamental ao Ambiente; Dever de Proteção Ambiental do Estado; Deveres Fundamentais de Proteção Ambiental dos Particulares; Princípio Constitucional da Solidariedade.
\end{abstract}

\begin{abstract}
The present study analyses the arising of the Socio-Environmental State of Law model, settled under the juridical-constitutional mark of the solidarity principle, characterizing the State's environmental protection duties, as well as the environmental fundamental duties of the private actors.

KEYWORDS: Socio-Environmental State of Law; Environmental Justice; Fundamental Right to a Healthy Environment; State's Environmental Protection Duties; Environmental Fundamental Duties of the Private Actors; Constitutional Principle of Solidarity.

SUMÁRIO: 1. Estado Socioambiental de Direito: a proteção ambiental como tarefa ou fim do Estado de Direito brasileiro contemporâneo. 1.1. Do Estado Liberal ao Estado Socioambiental de Direito. 1.2. Capitalismo Socioambiental. 1.3. Estado de Justiça Ambiental. 1.4. Estado de Segurança Ambiental. 1.5. O novo papel constitucional do Estado e da Sociedade no Estado Socioambiental de Direito. 2. O princípio da solidariedade como marco jurídico-constitucional do Estado Socioambiental de Direito. 2.1. O princípio constitucional da solidariedade em matéria ambiental. 2.2. Solidariedade entre cidadãos de diferentes Estados nacionais. 2.3. Solidariedade entre gerações humanas. 2.4. Solidariedade entre espécies naturais. 3. Conclusões articuladas.
\end{abstract}

Todos os seres humanos nascem livres e iguais em dignidade e direitos. Dotados de razão e consciência, devem agir uns para com os outros em espírito de fraternidade. ${ }^{1}$

\footnotetext{
* Mestre em Direito Público pela PUCRS (Bolsista do CNPq). Membro do NEDF - Núcleo de Estudos e Pesquisa de Direitos Fundamentais da PUCRS (CNPq). Defensor Público no Estado de São Paulo.

${ }^{1}$ Art. $1^{\circ}$ da Declaração Universal dos Direitos Humanos da ONU (1948).
} 


\section{ESTADO SOCIOAMBIENTAL DE DIREITO: A PROTEÇÃO AMBIENTAL COMO TAREFA OU FIM DO ESTADO DE DIREITO BRASILEIRO CONTEMPORÂNEO}

\subsection{Do Estado Liberal ao Estado Socioambiental de Direito}

O Relatório Nosso Futuro Comum (ou Relatório Bruntdland), datado de 1987, da Comissão Mundial sobre Meio Ambiente e Desenvolvimento da Organização das Nações Unidas, na ante-sala da Conferência das Nações Unidas sobre Meio Ambiente e Desenvolvimento (1992), reconhece a nossa dependência existencial em face da biosfera e destaca o quadro de desigualdade social na base do projeto de desenvolvimento econômico e social levado a cabo até agora no cenário mundial, revelando que uns poucos países e comunidades no mundo consomem e esgotam boa parte dos recursos naturais, ao passo que outros, em um número muito maior, consomem muito pouco e vivem na perspectiva da fome, da miséria, da doença e da morte prematura. ${ }^{2}$ O enfrentamento dos problemas ambientais e a opção por um desenvolvimento sustentável passam, portanto, necessariamente pela correção do quadro alarmante de desigualdade social e da falta de acesso da população pobre aos seus direitos sociais básicos, o que, diga-se de passagem, também é causa potencializadora da degradação ambiental. O projeto da modernidade ainda está em curso. Os direitos sociais foram deixados no meio do caminho, além de ter sido agregado um novo desafio existencial ao projeto: a proteção do ambiente. No contexto dos novos desafios postos no mundo contemporâneo para a sociedade, o Direito e o Estado, BENJAMIN destaca que o surgimento do direito ambiental está justamente vinculado às dificuldades do Estado (e dos cidadãos de um modo geral) de enfrentar uma nova e complexa situação posta no seio da sociedade industrial: a degradação ambiental. ${ }^{3}$

Já nas primeiras linhas traçadas para fundamentar o novo modelo de Estado de Direito que aponta no horizonte jurídico-constitucional contemporâneo impõe-se a justificativa acerca da preferência do autor pela expressão socioambiental, registrando-se a existência de inúmeros e diferentes termos para denominar o novo projeto da comunidade estatal, entre eles: Estado Pós-social ${ }^{4}$, Estado Constitucional Ecológico ${ }^{5}$,

\footnotetext{
2 “Há só uma Terra, mas não um só mundo. Todos nós dependemos de uma biosfera para conservarmos nossas vidas. Mesmo assim, cada comunidade, cada país luta pela sobrevivência e pela prosperidade quase sem levar em consideração o impacto que causa sobre os demais. Alguns consomem os recursos da Terra a um tal ritmo que provavelmente pouco sobrará para as gerações futuras. Outros, em número muito maior, consomem pouco demais e vivem na perspectiva da fome, da miséria, da doença e da morte prematura". Nosso Futuro Comum (Relatório Brundtland) - Comissão Mundial de Meio Ambiente e Desenvolvimento da ONU. 2.ed. São Paulo: Editora da Fundação Getúlio Vargas, 1991, p. 29.

${ }^{3}$ BENJAMIN, Antônio Herman. "Função ambiental”. In: BENJAMIN, Antônio Herman (Coord.). Dano Ambiental: Prevenção, Reparação e Repressão. São Paulo: Revista dos Tribunais, 1993, p. 15.

${ }^{4}$ Cfr., adotando a expressão Estado Pós-Social, PEREIRA DA SILVA, Vasco. Verde Cor de Direito: lições de Direito do Ambiente. Coimbra: Almedina, 2002, p. 24; PUREZA, José Manuel. Tribunais, natureza e sociedade: o direito do ambiente em Portugal. Lisboa: Cadernos do Centro de Estudos Judiciários, 1996, p. 27; e SARMENTO, Daniel. "Os direitos fundamentais nos paradigmas Liberal, Social e Pós-Social (Pós-modernidade constitucional?)”. In: SAMPAIO, José Adércio Leite (Coord.). Crise e Desafios da Constituição: perspectivas críticas da teoria e das práticas constitucionais brasileiras. Belo Horizonte: Del Rey, 2003, pp. 375-414.

${ }^{5}$ CANOTILHO, José Joaquim Gomes. "Estado Constitucional Ecológico e Democracia Sustentada". In: SARLET, Ingo Wolfgang (Org.). Direitos Fundamentais Sociais: estudos de Direito Constitucional, Internacional e Comparado. Rio de Janeiro/São Paulo: Renovar, 2003, pp. 493-508.
} 
Estado de Direito Ambiental ${ }^{6}$, Estado do Ambiente ${ }^{7}$, Estado Ambiental de Direito ${ }^{8}$, Estado de Bem-Estar Ambiental ${ }^{9}$, entre outros. A preferência pela expressão socioambiental resulta, como se verá ao longo do presente estudo, da necessária convergência das “agendas” social e ambiental num mesmo projeto jurídico-político para o desenvolvimento humano. O objetivo do Estado contemporâneo não é "pós-social”, em razão de o projeto de realização dos direitos fundamentais sociais (de segunda dimensão) não ter se completado, remanescendo a maior parte da população mundial (o que se apresenta de forma ainda mais acentuada na realidade brasileira e dos países em desenvolvimento de um modo geral) até os dias atuais desprovida do acesso aos seus direitos sociais básicos (e, inclusive, da garantia constitucional do mínimo existencial indispensável a uma existência digna). Há, portanto, um percurso político-jurídico não concluído pelo Estado Social.

A partir de tal premissa, deve-se ter em conta a existência tanto de uma dimensão social quanto de uma dimensão ecológica como elementos integrantes do núcleo essencial do princípio da dignidade da pessoa humana, sendo que somente um projeto jurídico-político que contemple conjuntamente tais objetivos constitucionais atingirá um quadro compatível com a condição existencial humana tutelada na nossa Lei Fundamental. De igual modo, HÄBERLE afirma que os objetivos estatais do Estado Ambiental, assim como do Estado Social, são, em seu conteúdo fundamental, conseqüências do dever jurídico-estatal de respeito e proteção da dignidade humana, no sentido de uma "atualização viva do princípio", em constante atualização à luz dos novos valores humanos que são incorporados ao seu conteúdo normativo, o que acaba por exigir uma medida mínima de proteção ambiental. ${ }^{10}$

Tanto as ideologias liberais quanto as ideologias socialistas, como acentua MORATO LEITE, não souberam lidar com, e nem mesmo contemplaram no seu projeto político, a crise ambiental, considerando que ambos, respectivamente, o capitalismo industrialista e o coletivismo industrialista, colocaram em operação um modelo industrial agressivo aos valores ambientais da comunidade. ${ }^{11} \mathrm{O}$ quadro contemporâneo de degradação e crise ambiental é fruto, portanto, dos modelos econômicos experimentados no passado, não se tendo cumprido a promessa de bem-estar para todos como decorrência da revolução industrial, mas um contexto de

\footnotetext{
${ }^{6}$ MORATO LEITE, José Rubens. Dano ambiental: do individual ao coletivo extrapatrimonial. São Paulo: Revista dos Tribunais, 2000, pp. 33-45; e MORATO LEITE, José Rubens. "Estado de Direito do Ambiente: uma difícil tarefa”. In: MORATO LEITE, José Rubens (Org.). Inovações em Direito Ambiental. Florianópolis: Fundação Boiteux, 2000, pp. 13-40.

${ }^{7}$ HÄBERLE, Peter. “A dignidade humana como fundamento da comunidade estatal”. In: SARLET, Ingo Wolfgang (Org.). Dimensões da Dignidade: ensaios de Filosofia do Direito e Direito Constitucional. Porto Alegre: Livraria do Advogado, 2005, p. 128.

${ }^{8}$ NUNES JUNIOR, Amandino Teixeira. “Estado ambiental de Direito”. In: Jus Navigandi, n 589, fevereiro/2005. Disponível em: http://www1.jus.com.br/doutrina/texto.asp?id=6340. Acesso em: 22.02.2005.

${ }^{9}$ PORTANOVA, Rogério. "Direitos humanos e meio ambiente: uma revolução de paradigma para o Século XXI”. In: BENJAMIN, Antônio Herman (Org.). Anais do $6^{\circ}$ Congresso Internacional de Direito Ambiental (10 anos da ECO-92: o Direito e o desenvolvimento sustentável). São Paulo: Instituto O Direito por um Planeta Verde/Imprensa Oficial, 2002, pp. 681-694.

${ }^{10}$ HÄBERLE, “A dignidade humana como fundamento...”, p. 130.

${ }^{11}$ MORATO LEITE, “Dano ambiental...”, p. 22.
} 
devastação ambiental planetária e indiscriminada. ${ }^{12}$ No mesmo sentido, PEREIRA DA SILVA destaca que o Estado Social “desconhecera em absoluto” a problemática ambiental, por estar imbuído de uma "ideologia otimista” do crescimento econômico, como "milagre" criador do progresso e de qualidade de vida. ${ }^{13}$ Somente com a crise do modelo de Estado Social ou de Providência, surgida no final dos anos 60 e cujos sintomas mais agudos só foram sentidos nos anos 70, com a denominada "crise do petróleo", que se obrigou a uma tomada generalizada de consciência acerca dos limites do crescimento econômico e da esgotabilidade dos recursos naturais. Também data desse período os relatórios do Clube de Roma sobre os limites do crescimento econômico. ${ }^{14}$

Diante de tais considerações, a proteção ambiental projeta-se como um dos valores constitucionais mais importantes a serem incorporados como tarefa ou objetivo do Estado de Direito neste início século XXI, porquanto, diante dos novos desafios impostos pela sociedade de risco diagnosticada por $\mathrm{BECK}^{15}$, diz respeito diretamente à concretização de uma existência humana digna e saudável e marca paradigmaticamente a nova ordem de direitos transindividuais que caracterizam as relações jurídicas cada vez mais massificadas do mundo contemporâneo. O processo histórico, cultural, econômico, político e social gestado ao longo século XX determinou o momento que se vivencia hoje no plano jurídico-constitucional, marcando a passagem do Estado Liberal ao Estado Social e chegando-se ao Estado Socioambiental (também Constitucional e Democrático), em vista do surgimento de direitos de natureza transindividual e universal que têm na proteção do ambiente o seu exemplo mais expressivo.

Com efeito, à luz especialmente dos seus deveres de proteção ${ }^{16}$ em relação aos direitos fundamentais e à dignidade humana, o Estado contemporâneo deve ajustar-se (e, se necessário, remodelar-se) a cada novo passo histórico no sentido de enfrentar como tarefa estatal as novas ameaças e riscos ecológicos que fragilizam a existência humana, tendo em vista, como refere HÄBERLE, um "processo dialético posto em marcha"17, que se renova constantemente no horizonte do projeto político-jurídico da comunidade estatal. Nessa perspectiva, é certeira a afirmação de HÄBERLE sobre a necessidade de um desenvolvimento mais reforçado de deveres e obrigações

\footnotetext{
${ }^{12}$ MORATO LEITE, “Dano ambiental...”, p. 22.

${ }^{13}$ PEREIRA DA SILVA, "Verde Cor de Direito...", p. 18.

${ }^{14}$ PEREIRA DA SILVA, “Verde Cor de Direito...”, pp. 17-18.

${ }^{15}$ BECK, Ulrich. La sociedad del riesgo: hacia una nueva modernidad. Tradução de Jorge Navarro, Daniel Jiménez e Maria Rosa Borras. Barcelona: Paidós, 2001.

${ }^{16}$ Sobre o tema dos deveres de proteção (ou imperativos de tutela) para com os direitos fundamentais depositados pela ordem constitucional na figura do Estado, à luz da jurisprudência do Tribunal Constitucional Federal alemão, DIMOULIS e MARTINS afirmam que esses foram identificados na hipótese do dever conferido ao ente estatal de tomar medidas no sentido de controlar os riscos e perigos derivados do desenvolvimento tecnológico, em razão do comprometimento dos direitos fundamentais à vida, à saúde e ao equilíbrio ambiental. Há, na hipótese, um dever estatal de garantia da segurança ou de prevenção de riscos. DIMOULIS, Dimitri; MARTINS, Leonardo. Teoria geral dos direitos fundamentais. São Paulo: Revista dos Tribunais, 2007, p. 123.

${ }^{17}$ HÄBERLE, Peter. Libertad, Igualdad, Fraternidad: 1789 como historia, actualidad y futuro del Estado constitucional. Tradução de Ignacio Gutiérrez Gutiérrez. Madrid: Editorial Trotta, 1998, p. 53.
} 
decorrentes da dignidade humana em vista do futuro humano, o que se justifica especialmente nas dimensões comunitária e ecológica da dignidade humana. Como refere o constitucionalista alemão, tal afirmativa já foi esporadicamente contemplada no âmbito constitucional alemão (art. 20a da Lei Fundamental), que, reconhecendo os "limites do crescimento" do Estado Social de Direito, tornou necessária a proteção do ambiente, enquanto um reforço da proteção da dignidade humana. ${ }^{18}$ Tal perspectiva também está contemplada na ordem constitucional brasileira, conforme se pode apreender dos arts. 170 (caput e inciso VI), 186 (inciso II) e 225, sedimentando um projeto jurídico-econômico marcado pelo princípio do desenvolvimento sustentável.

No sentido de combater a hipertrofia do indivíduo e a base axiológica marcadamente patrimonialista do modelo do Estado Liberal, o "novo" Estado de Direito projeta como seu estandarte axiológico o terceiro (e quase esquecido!) lema da Revolução Francesa, qual seja, a solidariedade (ou fraternidade), de cunho eminentemente existencial, comunitário e universalista. Nesse aspecto, a fim de reparar o débito social do projeto burguês do Estado Liberal e agregar a dimensão coletiva da condição humana alçada pelo Estado Social ${ }^{19}$, projeta-se, hoje, no horizonte jurídico da comunidade estatal o modelo de Estado Socioambiental, que, conjugando as conquistas positivas (em termos de tutela da dignidade humana) dos modelos de Estado de Direito que o antecederam, possa incorporar a tutela dos novos direitos transindividuais e, num paradigma de solidariedade humana (nas dimensões nacional e supranacional), projetar a comunidade humana num patamar mais evoluído de efetivação de direitos fundamentais (especialmente dos novos direitos de terceira dimensão ${ }^{20}$ ) e de concretização de uma vida humana digna e saudável a todos os seus membros. O ideário da Revolução Francesa - liberdade, igualdade (material) e fraternidade (ou solidariedade) -, adaptado a uma leitura contemporânea substanciosa e constitucional, ainda serve de bandeira a ser erguida e proclamada.

A edificação do Estado Socioambiental de Direito, é importante consignar, não representa um marco "ahistórico” (ou "marco zero”) na construção da comunidade político-jurídica estatal, mas apenas mais um passo num caminhar contínuo iniciado sob o marco do Estado Liberal, não obstante a importância das formulações jurídico-

\footnotetext{
${ }^{18}$ HÄBERLE, “A dignidade humana como fundamento...”, p. 102.

${ }^{19}$ Conforme destaca BERND SHULTE, à luz da Lei Fundamental alemão, o atributo "social” caracteriza um Estado que "assegura a cada pessoa uma existência humanamente digna, assiste ao fraco, oferece a cada pessoa possibilidades de desenvolvimento, concedendo-lhe em ampla medida oportunidades iguais e garantindo-lhe a sua quota-parte (Teilhabe) nos bens econômicos segundos critérios de justiça”. SHULTE, Bernd. "Direitos fundamentais, segurança social e proibição de retrocesso". In: SARLET, Ingo Wolfgang. Direitos Fundamentais Sociais: estudos de Direito Constitucional, Internacional e Comparado. Rio de Janeiro/São Paulo: Renovar, 2003, p. 306.

${ }^{20}$ Nesse prisma, PERREIRA DA SILVA destaca que “o Estado Pós-Social em que vivemos, no quadro de uma lógica constitutiva e infra-estrutural dirigida para a criação de condições para a colaboração de entidades públicas e privadas, está associado a uma terceira geração de direitos humanos em novos domínios da vida da sociedade, como é o caso do ambiente e da qualidade de vida, da proteção individual relativamente à informática e às novas tecnologias, da tutela da vida e da personalidade em face da genética, sendo ainda de incluir nesta categoria as garantias individuais de procedimento (o qual é entendido não apenas como instrumento de legitimação do poder mas também como modo de realização da proteção jurídica subjetiva)”. PEREIRA DA SILVA, “Verde Cor de Direito...”, p. 23.
} 
políticas de organização societária que o antecederam. O novo modelo de Estado de Direito objetiva uma salvaguarda cada vez maior da dignidade humana e de todos os direitos fundamentais (de todas as dimensões), em vista de uma construção histórica permanente dos seus conteúdos normativos, já que, como refere HÄBERLE, ao destacar a importância histórica da Revolução Francesa, em 1789, há uma eterna peregrinação, constituída de inúmeras etapas, em direção ao Estado Constitucional. ${ }^{21}$ PUREZA, nessa linha, refere que o modelo de Estado de Direito Ambiental revela o ganho de uma nova dimensão para completar o elenco presente dos fins fundamentais Estado de Direito contemporâneo (qual seja: o imperativo da proteção do ambiente), a qual se articula dialeticamente com as outras dimensões já plenamente consagradas ao longo do percurso histórico do Estado de Direito (proteção dos direitos fundamentais, realização de uma democracia política participativa, disciplina da atividade econômica pelo poder político democrático e realização de objetivos de justiça social). ${ }^{22}$

Com o olhar voltado para tal perspectiva, diante de possíveis conflitos entre os direitos fundamentais de diferentes dimensões, PEREIRA DA SILVA alerta para que

os valores ético-jurídicos da defesa do ambiente não esgotam todos os princípios e valores do ordenamento jurídico, pelo que a realização do Estado de Direito Ambiental vai obrigar à conciliação dos direitos fundamentais em matéria de ambiente com as demais posições jurídicas subjetivas constitucionalmente fundadas, quer se trate de direitos da primeira geração, como a liberdade e a propriedade, quer se trate de direitos fundamentais da segunda geração, como os direitos econômicos e sociais (o que, entre outras coisas, tem também como conseqüência que a preservação da natureza não significa pôr em causa o desenvolvimento econômico ou, ironizando, não implica o "retorno à Idade da Pedra"). ${ }^{23}$

Tal perspectiva ajusta-se à tese da indivisibilidade e interdependência dos direitos fundamentais de todas as diferentes dimensões, defendida no presente estudo. A harmonia do sistema de tutela da dignidade humana delineada pela tese referida, não obstante a inevitável ocorrência de conflitos ou colisões entre direitos fundamentais, que se dá pela própria complexidade das relações sociais, é medida indispensável a uma tutela integral e efetiva da pessoa. Nesse caminhar, CANÇADO TRINDADE, ao formular a sua crítica à concepção de "gerações de direitos humanas", com o que estamos de pleno acordo, destaca a "natureza complementar" de todos os direitos humanos. O eminente internacionalista pontua que por trás da perspectiva "fantasiosa" das gerações está uma visão fragmentária dos direitos humanos, a qual tem operado a postergação da realização de alguns dos direitos humanos, como ocorre com os direitos econômicos, sociais e culturais. ${ }^{24}$ Contra tal mal, a tese da unidade e indivisibilidade dos direitos humanos (e o mesmo ocorre com os direitos fundamentais) é o melhor

${ }^{21}$ HÄBERLE, “Libertad, Igualdad, Fraternidad...”, p. 58.

${ }^{22}$ PUREZA, José Manuel. Tribunais, natureza e sociedade: o direito do ambiente em Portugal. Cadernos do Centro de Estudos Judiciários. Lisboa: 1996, p. 27.

${ }^{23}$ PEREIRA DA SILVA, “Verde Cor de Direito...”, p. 28.

${ }^{24}$ TRINDADE, Antônio Augusto Cançado. Tratado de Direito Internacional dos Direitos Humanos. Volume I. 2.ed. Porto Alegre: SAFE, 2003, p. 43. 
antídoto, rompendo com qualquer hierarquização ou priorização da realização de direitos humanos em razão da sua precedência geracional.

O Estado de Direito contemporâneo, para CANOTILHO, apresenta as seguintes dimensões fundamentais: juridicidade, democracia, sociabilidade e sustentabilidade ambiental..$^{25}$ A seqüência das dimensões apresentada pelo constitucionalista português traça a evolução histórica de conquista e reconhecimento dos seus valores e princípios fundamentais. Desde a sua formulação "primitiva", o Estado de Direito vem passando por um processo evolutivo contínuo e dialético, reconhecendo e agregando novas dimensões político-jurídicas no seu horizonte constitutivo: o Estado Constitucional, o Estado Democrático, o Estado Social e o Estado Socioambiental. Da mesma forma como ocorre com a evolução dos direitos fundamentais, as dimensões do Estado de Direito se agregam e se somam para formar o arcabouço de princípios e valores consagrados pela sociedade em um processo histórico permanente e cumulativo. No transcorrer do processo civilizatório da humanidade, muitas foram as faces e etapas tomadas pelo Estado de Direito até evoluir para o que se entende hoje como a sua forma mais adequada à tutela da dignidade humana, especialmente em face dos novos desafios existenciais postos contemporaneamente pela degradação dos recursos naturais. Nesse sentido, CANOTILHO pontua que "a forma que na nossa contemporaneidade se revela como uma das mais adequadas para colher esses princípios e valores de um Estado subordinado ao direito é o Estado constitucional de Direito democrático e social ambientalmente sustentado." ${ }^{, 6}$

O constitucionalista português assevera, nesse sentido, que a qualificação de um Estado como Estado Ambiental traduz-se em duas dimensões jurídico-políticas relevantes: a) a obrigação do Estado, em cooperação com outros Estados e cidadãos ou grupos da sociedade civil, de promover políticas públicas (econômicas, educativas, de ordenamento) pautadas pelas exigências da sustentabilidade ecológica; e b) o dever de adoção de comportamentos públicos e privados amigos do ambiente de forma a dar expressão concreta à assunção da responsabilidade dos poderes públicos perante as gerações futuras. ${ }^{27}$

As lutas travadas pelo movimento ambientalista a partir da década de $60^{28}$ e que se estendem até os dias atuais - são materializadas na ordem constitucional e na formatação do Estado Socioambiental de Direito. A legitimidade da causa ambiental, e o seu posterior reconhecimento como direito fundamental, está justamente na movimentação da sociedade no sentido de reivindicar os valores de matriz ecológica

${ }^{25}$ CANOTILHO, José Joaquim Gomes. Estado de Direito. Cadernos Democráticos, nº 7. Fundação Mário Soares. Lisboa: Gradiva, 1998, p. 23.

${ }^{26}$ CANOTILHO, “Estado de Direito...”, p. 21.

${ }^{27}$ CANOTILHO, José Joaquim Gomes. Estado de Direito. Cadernos Democráticos nº 7. Fundação Mário Soares. Lisboa: Gradiva, 1998, p. 44.

${ }^{28} \mathrm{Cfr}$, acerca do movimento ambientalista, na literatura européia, a coletânea de artigos da ex-parlamentar do partido verde alemão PETRA KELLY. KELLY, Petra K. Por un futuro alternativo: el testimonio de una de las principales pensadoras-activistas de nuestra época. Barcelona: Paidós, 1997; e, no âmbito brasileiro, TAVOLARO, Sergio Barreira de Faria. Movimento ambientalista e modernidade: sociabilidade, risco e moral. São Paulo: Annablume/Fapesp, 2001, e LUTZEMBERGER, José. A. Fim do futuro? Manifesto Ecológico Brasileiro. Porto Alegre: Movimento/UFRGS, 1980. 
e de posicionar-se contra a degradação ambiental. Nesse compasso, como já sinalizado por CANOTILHO acima, há um perfil de atuação compartilhada entre o Estado e os atores privados na consecução do objetivo constitucional de tutela do ambiente. Esse é o conteúdo da norma constitucional expressa no art. 225, caput.

\subsection{Capitalismo socioambiental: rumo ao desenvolvimento sustentável}

O modelo do Estado Socioambiental difere substancialmente do Estado Liberal, já que, como refere CANOTILHO, “o ‘Estado do Ambiente’ não é um Estado liberal, no sentido de um Estado de polícia, limitado a assegurar a existência de uma ordem jurídica de paz e confiando que também o livre jogo entre particulares - isto é, uma 'mão invisível' - solucione os problemas do ambiente”. ${ }^{29}$ Ao contrário, o Estado Socioambiental tem um papel ativo e promocional dos direitos fundamentais, especialmente no que tange à tutela ambiental. TEIXEIRA propõe, à luz do conteúdo normativo expresso na Constituição Federal (art. 225), que o Estado deve levar em conta a crise ambiental e posicionar-se diante da sua tarefa de defesa do ambiente, cumprindo um papel intervencionista e implementador de novas políticas públicas para tal mister. ${ }^{30}$ O Estado Socioambiental aponta para a compatibilidade da atividade econômica com a idéia de desenvolvimento (e não apenas crescimento!) sustentável, na medida em que a "mão invisível" do mercado é substituída necessariamente pela “mão visível” do Direito, já que, como salienta LÓPEZ PINA, em prólogo à obra de HÄBERLE (Liberdade, Igualdade e Fraternidade),

el mercado no es un fin en si mismo, un espacio libre de Derecho extramuros del Estado e dela ética. La economía solo tiene servicio al servicio del Hombre, debiendo encontrar en ella su lugar no menos la "visible hand" del Derecho Constitucional que la "invisible hand" del mercado. ${ }^{31}$

Há uma tensão dialética permanente entre a proteção ambiental e o desenvolvimento econômico. Em face do forte conteúdo econômico inerente à utilização dos recursos naturais, e, conseqüentemente, das pressões de natureza político-econômicas que permeiam, na grande maioria das vezes, as medidas protetivas do ambiente, pontua ANTUNES que não se pode entender a natureza econômica da proteção jurídica do ambiente como um tipo de relação jurídica que privilegie a atividade produtiva em detrimento de um padrão de vida mínimo que deve ser assegurado aos seres humanos, mas que a preservação e a utilização sustentável e racional dos recursos ambientais devem ser encaradas de modo a assegurar um padrão constante de elevação da qualidade de vida, sendo, portanto, o fator econômico encarado como desenvolvimento, e não como crescimento. $^{32}$

O Estado Socioambiental de Direito, longe de ser um Estado “mínimo”, é um Estado regulador da atividade econômica, capaz de dirigí-la e ajustá-la aos valores e

${ }^{29}$ CANOTILHO, José Joaquim Gomes. "Privatismo, associacionismo e publicismo no Direito do Ambiente: ou o rio da minha terra e as incertezas do Direito Público”. In: Textos “Ambiente e Consumo”, Volume I. Lisboa: Centro de Estudos Jurídicos, 1996, p. 156.

${ }^{30}$ TEIXEIRA, Orci Paulino Bretanha. O direito ao meio ambiente ecologicamente equilibrado como direito fundamental. Porto Alegre: Livraria do Advogado, 2006, p. 104.

${ }^{31}$ PINA, Antonio López. Prólogo à obra de HÄBERLE, Libertad, Igualdad, Fraternidad...”, p. 15.

${ }^{32}$ ANTUNES, Paulo de Bessa. Direito Ambiental. 7.ed. Rio de Janeiro: Lúmen Júris, 2005, p. 23. 
princípios constitucionais, objetivando o desenvolvimento humano e social de forma ambientalmente sustentável. O princípio do desenvolvimento sustentável expresso no art. 170 (inciso VI) da Constituição Federal, confrontado com o direito de propriedade privada e a livre iniciativa (caput e inciso II do art. 170), também se presta a desmistificar a perspectiva de um capitalismo liberal-individualista em favor da sua leitura à luz dos valores e princípios constitucionais socioambientais. Com relação à pedra estruturante do sistema capitalista, ou seja, a propriedade privada, os interesses do seu titular devem ajustar-se aos interesses da sociedade e do Estado na determinação do exercício do seu direito. A ordem econômica constitucionalizada no art. 170 da Carta da República, com base também nos demais fundamentos constitucionais que lhe constituem e informam, expressa um capitalismo socioambiental, capaz de compatibilizar a livre iniciativa, a autonomia privada e a propriedade privada com a proteção ambiental e a justiça ambiental (e também social), tendo como o seu norte normativo "nada menos" do que a realização de uma vida humana digna e saudável (e, portanto, com qualidade ambiental) a todos os membros da comunidade estatal.

O estudo prévio de impacto ambiental (art. 225, § $1^{\circ}$, IV, da CF) exigido para a instalação de obra ou atividade causadora ou potencialmente causadora de significativa degradação ambiental é um mecanismo jurídico de ajuste da atividade econômica, bem como constitui um dever fundamental que limita o direito de propriedade e a livre iniciativa dos atores econômicos privados, conformando o princípio constitucional do desenvolvimento sustentável. Nesse prisma, DERANI pontua que o "espírito" da avaliação de impacto ambiental incorpora um processo de planejamento para a "sustentabilidade" das atividades econômicas, integrado por um conjunto de ações estratégicas em vista de uma melhoria (e também melhor distribuição) da qualidade de vida. ${ }^{33}$ TEIXEIRA também aponta para o poder de polícia como um instrumento conferido ao Estado viabilizador da sua intervenção na economia, de modo a fiscalizar e regulamentar as atividades poluidoras ou potencialmente poluidoras. ${ }^{34}$ A idéia central do desenvolvimento sustentável, como preceitua o princípio do poluidor-pagador, orienta no sentido de se incluírem sempre os custos ambientais (da mesma forma que os custos sociais) no "cálculo" da atividade produtiva, tendo em vista desestimular práticas econômicas incompatíveis com a proteção ambiental.

Em passagem da sua obra, PUREZA articula a idéia de que a incorporação da proteção ambiental como objetivo fundamental do Estado não é pacífica, em razão de transportar consigo, acima de tudo, uma reorientação radical das funções econômicas e sociais do Estado. ${ }^{35}$ Dessa forma, diferentemente da lógica limitativa, que estava em jogo entre Estado Liberal e o Estado Social, a questão decisiva para o Estado de Direito Ambiental não é a intensidade da intervenção econômica do Estado, mas sim o primado do princípio do destino universal dos bens ambientais, o que impõe como tarefa fundamental o controle jurídico do uso racional do patrimônio natural. Por fim, refere PUREZA que o Estado Ambiental assume abertamente o patrimônio natural e o ambiente como bens públicos, objeto de utilização racional (controlada, por exemplo,

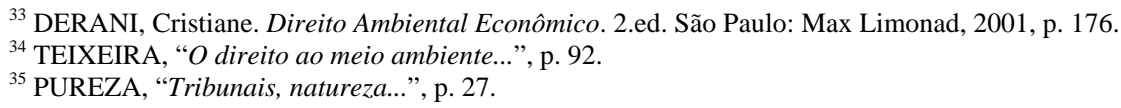


através de instrumentos fiscais ou administrativos), impondo balizas jurídicas que orientem toda a atividade econômica para um horizonte de solidariedade substancial. ${ }^{36}$ $\mathrm{O}$ art. 225, caput, da Lei Fundamental brasileira é partidário de tal compreensão, na medida em que dispõe ser o ambiente "bem de uso comum do povo".

À luz de tal perspectiva, MATEO assevera com precisão que o conceito de “desenvolvimento sustentável” vai mais além de uma mera harmonização entre a economia e a ecologia, incluindo valores morais relacionados à solidariedade ${ }^{37}$, o que contempla uma nova ordem de valores que devem conduzir a ordem econômica rumo a uma produção social e ambientalmente compatível com a dignidade de todos os integrantes do tecido social. O desenvolvimento econômico deve estar vinculado à idéia de uma melhoria substancial e qualitativa (e não apenas quantitativa em termos de crescimento econômico) da qualidade de vida. Com a mesma idéia de solidariedade, inclusive considerando a dimensão intergeracional desta, MILARÉ alerta para a relação entre "direito" e "dever" consubstanciada no princípio do desenvolvimento sustentável $^{38}$, na medida em que tal comando constitucional impulsiona, para além do direito individual e coletivo de viver e desenvolver-se em um ambiente ecologicamente equilibrado, a idéia de responsabilidade e dever das gerações humanas presentes em preservar e garantir condições ambientais favoráveis para o desenvolvimento adequado da vida das futuras gerações.

Os princípios que regem o desenvolvimento ambiental e socialmente sustentável devem orientar e vincular as condutas públicas e privadas no seu trânsito pela órbita econômica. Na linha defendida por DERANI, consideradas as prescrições constitucionais operantes sobre a ordem econômica, em razão da vinculação da garantia da propriedade privada ao desempenho de uma função social (arts. 5, XXIII, e 170, III), estaríamos diante de um capitalismo social ${ }^{39}$, ao passo que o desenvolvimento econômico encontra limites no interesse coletivo, devendo servir apenas como meio (e não um fim em si mesmo) de realização dos valores fundamentais do Estado de Direito contemporâneo.

Com razão, PEREZ LUÑO aponta para a opção constitucional espanhola de tutela ambiental, objetivando um modelo de desenvolvimento econômico e humano de resgate do "ser" (qualitativo) em detrimento de um modelo predatório do "ter" (quantitativo), o que se ajusta perfeitamente ao modelo de desenvolvimento econômico traçado pela Constituição brasileira, comprometido com a proteção ambiental e, acima de tudo, com a dignidade da pessoa humana, ampliada necessariamente para todos os membros da comunidade estatal. À luz do texto constitucional espanhol, pontua ainda PEREZ LUÑO que

con la protección de "un medio ambiente adecuado para el desarrollo de la persona” se hace eco de la inquietud contemporánea por ofrecer una alternativa

\footnotetext{
${ }^{36}$ PUREZA, “Tribunais, natureza...”, p. 28.

${ }^{37}$ MATEO, Ramón Martín. Manual de Derecho Ambiental. 3.ed. Navarra: Editorial Thomson/Aranzadi, 2003, p. 38.

${ }^{38}$ MILARÉ, Édis. "Princípios fundamentais do direito do ambiente”. In: Revista dos Tribunais, São Paulo: RT, n. 756, 1998, p. 64.

${ }^{39}$ DERANI, “Direito Ambiental Econômico...”, p. 34.
} 
al modelo, de signo puramente cuantitativo, del desarrollo económico y humano. La opción constitucional representa un expreso rechazo de la lógica del "tener", centrada en la acumulación exclusiva y excluyente de los productos de una explotación ilimitada de los recursos humanos y naturales; a favor del modelo del "ser", que exige el goce compartido (o inclusivo) de los frutos de un progreso selectivo y equilibrado. De que tal propósito no sea traicionado, o relegado al limbo de las buenas intenciones, depende el inmediato futuro de nuestra calidad de vida. ${ }^{40}$

Toda prática econômica desajustada aos valores ambientais e sociais no seu processo produtivo estará agindo de forma contrária aos ditames constitucionais, já que, como pontua ANTUNES ROCHA, a Constituição Federal traz o bem-estar social e a qualidade de vida como "princípios-base" da ordem econômica, sendo que a ordem social (aí também incluída a proteção ambiental), que era relegada a um plano secundário antes de 1988, ganhou "foro e título próprios" no novo texto constitucional. ${ }^{41}$ Pode-se dizer, portanto, que o constituinte brasileiro delineou no texto constitucional, para além de um capitalismo social, um capitalismo socioambiental, consagrando, portanto, a proteção ambiental como princípio-base da ordem econômica (art. 170, VI, da Lei Fundamental). ${ }^{42}$

\subsection{Estado de Justiça Ambiental}

A idéia de justiça ambiental ${ }^{43}$ também perpassa a abordagem da concepção de Estado Socioambiental de Direito, na medida em que esse, à luz de uma justiça distributiva e solidária, toma como fundamento a proteção das minorias (que, por vezes, tomam a forma de maiorias, como no caso brasileiro) expostas de forma desigual à degradação ambiental. CANOTILHO destaca a idéia de um Estado de Justiça Ambiental, o que conduz à proibição de práticas discriminatórias que tenham a questão ambiental de fundo, como decisão, seleção, prática administrativa ou atividade material referente à tutela do ambiente ou à transformação do território que onere injustamente indivíduos, grupos ou comunidade pertencentes a minorias populacionais em virtude de raça, situação econômica ou localização geográfica. ${ }^{44}$ A “injustiça ambiental” se revela de diversas formas, mas, assim como a "injustiça social”, afeta de forma mais intensa os cidadãos mais desfavorecidos economicamente, os quais possuem um acesso mais restrito aos serviços públicos essenciais (água, saneamento básico, educação, saúde, etc.), bem como dispõem de um acesso muito mais limitado à informação de natureza ambiental, o que acaba por comprimir a sua

\footnotetext{
${ }^{40}$ PÉREZ LUÑO, Antonio Enrique. Derechos Humanos, Estado de Derecho y Constitución. 5.ed. Madrid: Editorial Tecnos, 1995, p. 478.

${ }^{41}$ ROCHA, Cármen Lúcia Antunes. “Constituição e Ordem Econômica”. In: FIOCCA, Demian; GRAU, Eros Roberto (Orgs.). Debate sobre a Constituição de 1988. São Paulo: Paz e Terra, 2001, p. 12.

42 “Art. 170 (...) VI - a defesa do meio ambiente, inclusive mediante tratamento diferenciado conforme o impacto ambiental dos produtos e serviços e de seus processos de elaboração e prestação.”

${ }^{43}$ Também sobre a idéia de justiça ambiental e de um Estado de Justiça Ambiental, conferir a obra de MORATO LEITE, José Rubens; AYALA, Patryck de Araújo. Direito Ambiental na Sociedade de Risco. São Paulo: Forense Universitária, 2002, pp. 28-39.

${ }^{44}$ CANOTILHO, “Privatismo, associacionismo e publicismo...”, pp. 157-158.
} 
autonomia e liberdade de escolha, impedindo que evitem determinados riscos ambientais por absoluta (ou mesmo parcial) falta de informação e conhecimento.

Para reforçar tal entendimento, BECK refere que determinados grupos sociais, em razão do seu baixo poder aquisitivo, encontram-se mais vulneráveis a certos aspectos da degradação ambiental, em que pese existir, de certa forma, uma dimensão “democrática” da degradação ou poluição ambiental, que atinge a todos de forma igual (como, por exemplo, a poluição atmosférica, o aquecimento global, etc.), rompendo com a concepção tradicional de classes sociais. ${ }^{45}$ Como exemplo, basta fotografar a realidade dos grandes centros urbanos brasileiros onde as populações mais carentes são comprimidas em direção às áreas mais degradas do ambiente urbano (conseqüentemente, menos disputadas pela especulação imobiliária), geralmente próximas a lixões ${ }^{46}$, recursos hídricos contaminados e áreas industriais. Aí fica exposta a conexão entre o acesso aos direitos sociais básicos (como saúde, saneamento básico, moradia, alimentação, etc.) e a degradação ambiental, sendo que os grupos sociais mais pobres acabam tendo os seus direitos fundamentais violados duplamente, ou seja, tanto em face dos seus direitos sociais como também em relação aos seus direitos ambientais.

\subsection{Estado de Segurança Ambiental}

Em vista do atual contexto de desenvolvimento tecnológico e industrial das sociedades contemporâneas, o sociólogo alemão ULRICH BECK publicou, em 1986, a sua obra sobre a sociedade de risco (Risikogeselshaft) ${ }^{47}$, diagnosticando o contexto dos riscos existenciais e ambientais enfrentados pela humanidade em vista do enorme poder destrutivo das "novas” tecnologias desenvolvidas pela ciência (pós) moderna. BECK construiu a teoria da "sociedade de risco" a partir da perspectiva das ciências sociais, inserindo a degradação ambiental no centro da teoria social. Entre os perigos ecológicos referidos por BECK em sua obra, podem-se destacar os acidentes nucleares, a liberação de substâncias químicas em grande escala, a alteração e manipulação da composição genética da flora e da fauna do planeta, os quais colocam até mesmo a possibilidade de autodestruição das sociedades humanas. ${ }^{48}$

Assim, outro fator importante na configuração do Estado Socioambiental de Direito diz respeito à questão da segurança ambiental, que, para além da dimensão social, busca resguardar os cidadãos ante as novas violações da sua dignidade e dos seus direitos fundamentais em razão dos riscos ambientais produzidos pela sociedade (pós-industrial) de risco contemporânea. ${ }^{49}$ Nesse sentido, GOLDBLAT, a partir da

\footnotetext{
45 BECK, Ulrich. La sociedad del riesgo: hacia una nueva modernidad. Tradução de Jorge Navarro, Daniel Jiménez e Maria Rosa Borras. Barcelona: Paidós, 2001, pp. 40-41.

${ }^{46}$ O premiado documentário "Ilha das Flores" do cineasta gaúcho Jorge Furtado registrou de forma contundente a realidade degradante das comunidades humanas que se alimentam dos lixos na proximidade da Capital gaúcha.

${ }^{47}$ Cfr. BECK, Ulrich. La sociedad del riesgo: hacia una nueva modernidad. Barcelona: Paidós, 2001; BECK, Ulrich; GIDDENS, Anthony; LASH, Scott. Modernização reflexiva: política, tradição e estética na ordem social moderna. São Paulo: Editora UNESP, 1997.

${ }^{48}$ GOLDBLAT, “Teoria social e ambiente...”, p. 232.

${ }^{49}$ Nesse prisma, BODIN DE MORAES destaca que "as novas questões, postas pelas manipulações genéticas, pela reprodução assistida, pela energia nuclear, pelas agressões ao meio ambiente, pelo desenvolvimento da cibernética, configuram 'situações-problema' cujos limites não poderão ser decididos internamente,
} 
análise que faz da obra de BECK, afirma a incapacidade da forma de Estado de Direito que se tem hoje de enfrentar os riscos ambientais gerados pela sociedade de risco contemporânea, uma vez que a esfera pública convencional do Estado democrático representativo tornou-se incapaz de lutar adequadamente contra a escalada de riscos e incertezas com que é confrontada, ao mesmo tempo em que o projeto do Estado Providência teria esgotado as suas energias utópicas. ${ }^{50} \mathrm{O}$ Estado de Direito, a fim de promover a tutela da dignidade humana frente aos novos riscos ambientais e insegurança gerados pela sociedade tecnológica contemporânea, deve ser capaz de conjugar os valores fundamentais que emergem das relações sociais e, através das suas instituições democráticas, garantir aos cidadãos a segurança necessária à manutenção e proteção da vida com qualidade ambiental.

A concepção de Estado de Segurança desenvolvida por BECK vincula a legitimidade das instituições do Estado na manutenção da segurança dos cidadãos em termos ecológicos. O sociólogo alemão traz o conceito de irresponsabilidade organizada para explicar como e porque as instituições da sociedade moderna devem reconhecer inevitavelmente a realidade da catástrofe, ao mesmo tempo em que também a negam, evitando a indenização e o controle. Assim, a consciência do perigo em grande escala e de riscos catastróficos provoca uma dinâmica de transformação política e cultural que abala as burocracias do Estado, desafia o predomínio da ciência e traça de novo as fronteiras e linhas de combate da política contemporânea. ${ }^{51}$

HABERMAS também chega a falar em uma nova dimensão estatal: a do Estado de Segurança (Sicherheitstaat), ou de prevenção (Präventionstaat), fundado no princípio da solidariedade e na prevenção coletiva, e que, sucedendo o Estado de Direito (Rechtstaat) e o Estado Social (Sozialstaat), tem ampliadas a base financeira (Geldbasis) e a base do conhecimento (Wissensbasis)". ${ }^{2}$ À luz da perspectiva da segurança como tarefa do Estado contemporâneo, MORATO LEITE e AYALA destacam que “o Estado de Direito Ambiental traz consigo um típico direito pós-moderno, fruto da sociedade científico-técnico-industrial”. ${ }^{53}$ Assim, a tarefa estatal de segurança é resultado de todo o potencial destrutivo inerente à técnica contemporânea.

Com efeito, TORRES destaca que, em razão da configuração contemporânea de um "Estado da Sociedade de Risco", o qual tem como característica a idéia de uma sociedade de riscos, em oposição à sociedade industrial que dava sustentação ao Estado de Bem-Estar Social ou Estado Providência, é importante estabelecer os novos princípios que regem as novas relações sociais do risco, bem como redesenhar o relacionamento entre as atribuições do Estado e da própria sociedade. ${ }^{54}$ Nesse sentido,

estabelecidos pelos próprios biólogos, físicos ou médicos, mas deverão ser resultantes de escolhas éticopolítico-jurídicas da sociedade”. BODIN DE MORAES, Maria Celina. Danos à pessoa humana: uma leitura Civil-Constitucional dos danos morais. Rio de Janeiro/São Paulo: Renovar, 2003, p. 61.

${ }^{50}$ GOLDBLAT, David. Teoria Social e Ambiente. Tradução de Ana Maria André. Lisboa: Instituto Piaget, 1996, p. 237.

${ }^{51}$ GOLDBLAT, “Teoria social e ambiente...”, p. 230.

52 Apud TORRES, “Tratado de Direito...”, p. 179.

${ }^{53}$ MORATO LEITE; AYALA, “Direito Ambiental na...”, p. 30.

${ }^{54}$ TORRES, Ricardo Lobo. Tratado de Direito Constitucional Financeiro e Tributário. Volume II: Valores e Princípios Constitucionais Tributários. Rio de Janeiro/São Paulo/Recife: Renovar, 2005, pp. 176-177. 
TORRES assevera que, em que pese os riscos e inseguranças da sociedade moderna não poderem ser eliminados, há que ser aliviados por mecanismos de segurança social, econômica e ambiental, postulando pela adoção de novos princípios éticos e jurídicos ${ }^{55}$. Assim, os princípios da transparência, da responsabilidade, do custo-benefício, da solidariedade social e da solidariedade do grupo passam a fundamentar as exações necessárias ao financiamento das garantias da segurança social. ${ }^{56} \mathrm{~A}$ tal grupo de princípios deve ser agregado também o princípio da precaução, como comando jurídico-constitucional a trilhar um caminho de "menos riscos" ou "riscos controlados" para a comunidade humana diante das novas tecnologias, muitas com suas conseqüências ainda não plenamente conhecidas e controladas. Por fim, deve-se ter em conta que os riscos (ou ao menos certos riscos) são inerentes e inevitáveis ao desenvolvimento tecnológico e ao caminhar da humanidade; no entanto, a dimensão dos novos riscos ambientais toma uma feição completamente nova, já que, como nunca ocorrido em outro momento da nossa História, coloca a nossa própria sobrevivência como espécie em “cheque-mate”.

\subsection{O novo papel constitucional do Estado e da Sociedade no Estado} Socioambiental de Direito

Na medida em que a proteção do ambiente é colocada na estrutura constitucional do Estado brasileiro como dever de proteção estatal, e também como direito fundamental da pessoa humana, há que se remodelar a estrutura do Estado no intuito de traçar, de forma "transversal" e cooperativa, a atuação de todos os seus poderes políticos, entes estatais, órgãos administrativos, etc., a fim de perseguir e atingir tal objetivo. Diante de tal contexto, é possível demarcar o novo papel constitucional do Estado em face da tutela do ambiente, tendo, inclusive, o art. 225, $\S 1^{\circ}$, da Constituição, arrolado uma série de tarefas ambientais para os poderes públicos. A proteção do ambiente passa, de forma definitiva, a constituir-se como objetivo ou fim constitucional do Estado de Direito brasileiro.

Nesse contexto, TORRES afirma que diante da pluralidade de interesses em jogo na sociedade de riscos, essa se configura por ser necessariamente uma sociedade litigiosa, o que permite caracterizar, inclusive, um novo esquema de separação de poderes, onde se destacam a flexibilização da legalidade tributária, a tipificação administrativa e a judicialização da política. ${ }^{57}$ Com efeito, outro aspecto importante do modelo de Estado de Direito contemporâneo, como refere TORRES, diz respeito ao novo papel assumido pelas instituições políticas e sociais no enfrentamento da crise ambiental, merecendo destaque para um papel mais ativo tanto do Ministério Público quanto do Judiciário, especialmente na defesa dos direitos difusos, em cooperação com as instituições sociais, afastando-se da missão neutra que desempenhavam na sociedade industrial. ${ }^{58}$ De igual modo, é possível destacar também o novo perfil constitucional da Defensoria Pública impulsionada pela "Reforma do Judiciário",

\footnotetext{
${ }^{55}$ TORRES, “Tratado de Direito...”, p. 178.

${ }^{56}$ TORRES, “Tratado de Direito...”, p. 179

57 TORRES, “Tratado de Direito...”, p. 180.

${ }^{58}$ TORRES, “Tratado de Direito...”, p. 180.
} 
através da Emenda Constitucional 45/2004, e mais recentemente pela inserção da instituição no quadro dos legitimados para a propositura da ação civil pública (art. $5^{\circ}$ da Lei $\left.\mathrm{n}^{\circ} 7.437 / 85\right)$. Consoante se observou, há um papel mais ativo e promocional dos direitos fundamentais a cargo do Poder Público, representado tanto na atuação dos Poderes Executivo, Legislativo e Judiciário quanto na atuação de instituições como o Ministério Público e a Defensoria Pública, estando todos vinculados à salvaguarda do direito fundamental ao ambiente.

Com relação ao papel cada vez mais ativo do Ministério Públicos (Estadual e Federal) no âmbito da tutela de interesses transindividuais, especialmente ambiental, HERMAN BENJAMIN destaca que, ao contrário dos seus similares europeus, o Ministério Público brasileiro joga um papel fundamental na proteção do ambiente, atuando em todas as formas de implementação da legislação ambiental como: de forma preventiva e administrativa ao fiscalizar estudos de impacto ambiental e ao instaurar inquérito civil preventivo; na esfera judicial, reparatória ou repressiva, ao propor ação civil pública ou ação penal. ${ }^{59}$

No que diz com a Defensoria Pública, esta cumpre um papel constitucional essencial na tutela e implementação dos direitos fundamentais de todas as dimensões ou gerações, pautando-se, inclusive, pela perspectiva da integralidade, indivisibilidade e interdependência de todas elas. ${ }^{60}$ Da mesma forma que a Defensoria Pública atua na tutela dos direitos civis e políticos (ou de primeira dimensão), opera também, e de forma exemplar, no sentido de tornar efetivos os direitos econômicos, sociais, culturais (ou de segunda dimensão). Nessa linha, com o surgimento dos direitos fundamentais de solidariedade (ou de terceira dimensão), como é o caso da proteção do ambiente, automaticamente a tarefa constitucional de zelar por eles é atribuída à Defensoria Pública. As dimensões de direitos fundamentais, na sua essência, materializam os diferentes conteúdos integrantes do princípio da dignidade humana, o qual se apresenta como o pilar da arquitetura constitucional e objetivo maior a ser perseguido na atuação da Defensoria Pública.

Para certificar tal "estado da arte” da atuação institucional da Defensoria Pública no âmbito do Estado Socioambiental de Direito brasileiro, registra-se a recente inclusão da "instituição cidadã" no rol dos entes legitimados para a propositura da ação civil pública (art. $5^{\circ}$ da Lei ${ }^{0}$ 7.347/85, com redação dada pela Lei no 11.448/07). Tal mudança legislativa transpõe para o plano infraconstitucional o novo perfil dado à Defensoria Pública a partir da Reforma do Poder Judiciário, levada a cabo através da Emenda

59 BENJAMIN, Antônio Herman. "A implementação da legislação ambiental: o papel do Ministério Público”. In: BENJAMIN, Antônio Herman (Coord.). Dano Ambiental: Prevenção, Reparação e Repressão. São Paulo: Revista dos Tribunais, 1993, p. 371.

${ }^{60}$ Nesse prisma, merece destaque a Declaração e Programa de Ação de Viena (1993), promulgada na $2^{\text {a }}$ Conferência Mundial sobre Direitos Humanos, a qual estabeleceu no seu art. $5^{\circ}$ que "todos os direitos humanos são universais, indivisíveis, interdependentes e inter-relacionados”, reconhecendo que as diferentes dimensões de direitos humanos conformam um sistema integrado de tutela da dignidade humana. Sobre o tema, cfr. WEIS, Carlos. Direitos humanos contemporâneos. São Paulo: Malheiros, 2006, 117-121; e SCHÄFER, Jairo. Classificação dos direitos fundamentais: do sistema geracional ao sistema unitário. Porto Alegre: Livraria do Advogado, 2005. 
Constitucional $n^{\circ} 45 / 2004^{61}$. A legitimidade da Defensoria Pública para a propositura da ação civil pública, nesse prisma, força ainda mais a abertura das portas do Judiciário às demandas coletivas dos pobres do Brasil (no que tange aos seus interesses individuais homogêneos, coletivos em sentido estrito e difusos), ampliando o seu acesso à justiça. Assim, da mesma forma como ocorria anteriormente em face dos direitos liberais e dos direitos sociais, hoje a atuação da Defensoria Pública está atrelada de forma indissociável à tutela dos direitos difusos, dentre os quais desponta como paradigma a proteção do ambiente (art. 225, da Lei Fundamental brasileira) ${ }^{62}$. A nova missão constitucional, como referido em passagem anterior, encontra a sua legitimidade na própria tese da interdependência e indivisibilidade dos direitos fundamentais (e humanos).

A Defensoria Pública, nessa perspectiva, está perfeitamente legitimada a atuar como "guardiã" do direito fundamental ao ambiente na ordem jurídico-constitucional brasileira. Tal tarefa constitucional conferida à Defensoria Pública ganha ainda maior relevância quando está em causa a proteção de um patamar mínimo de qualidade ambiental, sem o qual a vida humana não pode se desenvolver com dignidade. Infelizmente, tal "retrato" de degradação ambiental é perfeitamente enquadrado nos grandes centros urbanos, onde uma massa expressiva da população carente é comprimida a viver próxima a áreas poluídas e degradadas (ex. próximas a lixões, pólos industriais, rios e córregos poluídos, encostas de morros sujeitas a desabamentos, etc.). A Defensoria Pública, diante de tal contexto, deve movimentar-se na defesa de tais cidadãos, fazendo com que seja garantido a eles um padrão mínimo de qualidade ambiental no local onde trabalham e sediam, de um modo geral, as suas existências.

No tocante ao papel de tutela ambiental conferido ao Poder Público, FARIAS trabalha com a idéia de uma ideologia constitucional ecológica na nova configuração do Estado de Direito brasileiro (Pós-1988), a partir da irradiação da normatividade da proteção do ambiente para todo o texto constitucional, ao afirmar que "a ideologia, adotada na Constituição da República, permite que se fale em Estado de Direito Ambiental, o que impregna todas as normas que se relacionam com o vasto leque do domínio normativo da expressão 'meio ambiente”,63. A transversalidade, expressão que cada vez ganha maior projeção político-administrativa para a abordagem ambiental, diz respeito exatamente à idéia de irradiação das normas ambientais para todas as esferas do Poder Público, alcançando, inclusive, a sociedade, a ponto de modelar comportamentos (com uma carga maior de responsabilidades e deveres) em favor da defesa ecológica.

Outra característica importante do Estado Socioambiental de Direito, que também revela a sua dimensão democrática, diz respeito à "tutela compartilhada público-privada"

\footnotetext{
${ }^{61}$ No sentido de aprofundar ainda mais o processo constitucional de fortalecimento da Defensoria Pública, tramita no Congresso Nacional a PEC 487.

${ }^{62}$ Nessa perspectiva, de forma exemplar, a lei que criou a Defensoria Pública do Estado de São Paulo (Lei Complementar $n^{\circ}$ 988, de 09 de janeiro de 2006) elencou, entre as suas atribuições institucionais, a promoção da "tutela dos direitos humanos em qualquer grau de jurisdição, inclusive perante os sistemas global e regional de proteção dos direitos humanos” (art. 5, VI, “b”), "tutela do meio ambiente, no âmbito de suas finalidades institucionais” (art. 5, VI, “e”) e "ação civil pública para tutela de interesse difuso, coletivo ou individual homogêneo” ((art. 50, VI, “g”).

${ }^{63}$ FARIAS, Paulo José Leite. Competência federativa e proteção ambiental. Porto Alegre: Sergio Antônio Fabris Editor, 1999, p. 226.
} 
do bem ambiental, ou seja, a possibilidade da proteção ambiental ser promovida tanto pelo Estado quanto pela sociedade, em vista de uma "recusa à estatização ou publicização" (como refere CANOTILHO ${ }^{64}$ ) da proteção do ambiente, já que esta última toma a forma de "dever" de todos os membros da comunidade estatal, e não apenas dos poderes públicos. A Constituição brasileira registrou de forma expressa a idéia de uma tutela ambiental levada a cabo tanto pelo Estado quanto pela sociedade ao impor ao Poder Público e à coletividade o dever de defender e preservar o ambiente para as presentes e futuras gerações (caput do art. 225,). Tal abordagem da tutela ambiental revela a idéia de solidariedade que perpassa o tratamento constitucional conferido à matéria, ao passo que a responsabilidade e o dever de proteção do ambiente são compartilhados entre o Estado e a sociedade, registrando uma marca importante do Estado Socioambiental de Direito, ao remodelar os papéis políticos e jurídicos do Estado e da sociedade. Registra-se, assim, o “movimento jurídico” de ampliação normativa do princípio da solidariedade, que acaba por ventilar no ordenamento jurídico brasileiro novos institutos - como, por exemplo, a boa-fé objetiva, a função social da propriedade e do contrato, o abuso de direito, os deveres fundamentais conexos e autônomos, a eficácia dos direitos fundamentais nas relações entre particulares, entre outros - que têm como função estabelecer uma nova postura dos particulares nas suas relações privadas e públicas. Tal perspectiva é importante para compreender a nova condição jurídica e papel constitucional atribuído à sociedade na consecução dos direitos fundamentais, e especialmente da proteção ambiental.

Com base na reflexão proposta até aqui, faz sentido colocar a necessidade de repensar o "pacto social”, em vista de contemplar o novo papel que o Estado e a sociedade desempenham no âmbito do Estado Socioambiental de Direito. Como refere PEREIRA DA SILVA, da mesma forma que a crise do Estado-Providência obrigou a repensar e renovar o "pacto social”, na tentativa de reequacionar o papel do Estado na sociedade e de dar resposta às necessidades sociais acrescidas em razão de novas ameaças dos poderes públicos e privados, também a "questão ecológica” (como outrora a questão social, mas também ainda a questão social) vai implicar a assunção de novas tarefas estatais ${ }^{65}$, além de projetar uma nova postura política (e também jurídica) para a sociedade civil, que, especialmente sob o marco normativo da solidariedade, deverá compartilhar com o Estado (não obstante em menor intensidade) a carga de responsabilidades e deveres de tutela do ambiente (para as presentes e futuras gerações). Assim como uma nova feição estatal se delineia, também um novo sujeito político deve emergir de tal conjuntura político-jurídica comprometida com o futuro.

2. O PRINCÍPIO DA SOLIDARIEDADE COMO MARCO JURÍDICOCONSTITUCIONAL DO ESTADO SOCIOAMBIENTAL DE DIREITO

2.1. O princípio constitucional da solidariedade em matéria ambiental

O princípio da solidariedade renasce como Fênix das cinzas jurídicas da Revolução

${ }^{64}$ CANOTILHO, José Joaquim Gomes. "Privatismo, associacionismo e publicismo no Direito do Ambiente: ou o rio da minha terra e as incertezas do Direito Público”. In: Textos Ambiente e Consumo, Volume I. Lisboa: Centro de Estudos Jurídicos, 1996, p. 154.

${ }^{65}$ PEREIRA DA SILVA, “Verde Cor de Direito...”, p. 24. 
Francesa para transformar-se no novo marco jurídico-constitucional do Estado Socioambiental de Direito contemporâneo. ${ }^{66}$ No compasso das promessas não cumpridas da modernidade, os princípios da liberdade e da igualdade, como os marcos normativos, respectivamente, do Estado Liberal e do Estado Social (de Direito), não deram conta sozinhos de contemplar uma vida digna e saudável a todos os integrantes da comunidade humana, deixando para os juristas contemporâneos uma obra normativa ainda inacabada. Nesse horizonte, o princípio da solidariedade aparece como mais uma tentativa histórica de realizar na integralidade o projeto da modernidade, concluindo o ciclo dos três princípios revolucionários: liberdade, igualdade e fraternidade. ${ }^{67} \mathrm{O}$ princípio da solidariedade busca continuar na edificação de uma comunidade estatal que teve o seu marco inicial com o Estado Liberal, alicerçando agora novos pilares constitucionais ajustados a nova realidade social e desafios existenciais postos no espaço históricotemporal contemporâneo. ${ }^{68}$

O art. $1^{\circ}$ da Declaração Universal dos Direitos Humanos da ONU (1948) coloca de forma clara o projeto da modernidade referido, situando todos os princípios revolucionários (liberdade, igualdade e fraternidade), ademais de destacar o princípio fundamental da dignidade da pessoa humana, que, diga-se de passagem, desde as luzes lançadas por KANT sobre a razão e a moral humanas, constitui a pedra fundamental da edificação constitucional do Estado Socioambiental de Direito contemporâneo.

Art. $1^{0}$. Todos os seres humanos nascem livres e iguais em dignidade e direitos. Dotados de razão e consciência, devem agir uns para com os outros em espírito e fraternidade.

Com tal premissa de continuidade do projeto jurídico-político moderno, SARMENTO destaca que, ao invés de abandonar o ideário da Modernidade, deve-se aprofundá-lo, sobretudo nas sociedades periféricas (pré-modernas sob certos aspectos), como é o caso da brasileira, que enfrentam carências já solucionadas nos países desenvolvidos. E, a partir de uma perspectiva racional, ressalta o autor que cumpre insistir, mais e mais, na luta pela implementação dos grandes valores do Iluminismo, da liberdade, da igualdade, da democracia e da solidariedade. ${ }^{69} \mathrm{E}$, para cumprir com

\footnotetext{
${ }^{66}$ No mesmo sentido, TORRES refere que, em que pese a solidariedade, como sinônimo da fraternidade, ter sido valor fundante do Estado de Direito e já aparecer na trilogia da Revolução Francesa (liberdade, igualdade e fraternidade), o pensamento jurídico posterior a KANT exacerbou a idéia de liberdade, diluindo-a na de legalidade, com o que ficaram esquecidas as idéias de justiça e solidariedade. TORRES, “Tratado de Direito...”, pp. 180-181. Também HÄBERLE, afirma a existência de um déficit de elaboração jurídico-positiva e ético-social do postulado da fraternidade de 1789 na atualidade e no futuro Estado constitucional, guardando especial importância a sua aplicação no que tange à proteção ambiental, juntamente com o princípio da responsabilidade. HÄBERLE, “Libertad, Igualdad, Fraternidad...”, p. 90.

${ }^{67}$ Registra-se que no presente trabalho as expressões "solidariedade" e "fraternidade" serão tomadas como sinônimos, não obstante a existência de divergência doutrinária a respeito de tal correspondência entre os conceitos. No mesmo sentido, atribuindo a identidade aos conceitos, TORRES, “Tratado de Direito...”, p. 181.

${ }^{68}$ Nesse prisma, em que pese não se encontrar em vigor, destaca-se a Carta dos Direitos Fundamentais da União Européia que prevê logo no início do seu preâmbulo, à luz do projeto da modernidade aludido anteriormente, que a comunidade estatal que constitui está alicerçada "nos valores indivisíveis e universais da dignidade do ser humano, da liberdade, da igualdade e da solidariedade”, bem como nos princípios da democracia e do Estado de Direito.

${ }^{69}$ SARMENTO, Daniel. Direitos Fundamentais e Relações Privadas. Rio de Janeiro: Lumen Juris, 2004, p. 64.
} 
o projeto iluminista, há especial destaque para o fortalecimento constitucional do princípio da solidariedade, reequacionando as responsabilidades de tutela dos direitos fundamentais entre o Estado e a sociedade. Nesse compasso, SARMENTO destaca que, em vista da eficácia horizontal dos direitos fundamentais, incluídos neles os direitos sociais, recupera-se a noção de solidariedade, revestindo-a de juridicidade, o que confere aos poderes econômicos privados não apenas o dever moral de garantir certas prestações sociais para as pessoas carentes com que se relacionarem, mas também, em certas situações, a obrigação jurídica de fazê-lo. ${ }^{70}$

O "renascimento" do princípio da solidariedade para o Direito tomou forma principalmente a partir da segunda metade do século XX (Pós-Segunda Guerra Mundial), especialmente em face das Constituições dos Estados nacionais promulgadas ao longo desse período, que, como ocorrido com a Constituição brasileira de 1988 (art. $1^{\circ}, \mathrm{III}$ ), acabaram por se construírem sob o marco fundamental da dignidade humana, corroborando, como refere BODIN DE MORAES, a idéia de "primazia das situações existenciais sobre as situações de cunho patrimonial”71. A Constituição Federal traz o princípio da solidariedade como objetivo da República no seu art. $3^{\circ}$, I, ao estabelecer a “construção de uma sociedade livre, justa e solidária”, além de destacar também como objetivo, a "erradicação da pobreza e da marginalização social e a redução das desigualdades sociais e regionais”, o que estabelece um novo marco normativoconstitucional, consolidando a solidariedade como princípio e valor constitucional. ${ }^{72}$

Uma das principiais tensões axiológico-normativas na conformação do Estado Socioambiental de Direito, como outrora verificado no conflito entre liberdade e igualdade levado a cabo na edificação do Estado Social, reside justamente no enfrentamento entre liberdade e solidariedade. No entanto, o conflito é apenas aparente, já que ambos os princípios (e valores) têm o seu conteúdo estabelecido de forma sistemática no ordenamento jurídico, objetivando ambos a uma tutela integral da dignidade humana. Na abordagem que faz do "direito-dever de solidariedade social”, BODIN DE MORAES ressalta que não se trata em verdade de impor limites à liberdade individual, atribuindo necessariamente maior relevância à solidariedade, mas sim da conformação de ambos os princípios em face da proteção da dignidade humana, o que, à luz do caso concreto, poderá fazer com que "a medida de ponderação para a sua adequada tutela propenda ora para a liberdade, ora para a

\footnotetext{
${ }^{70}$ SARMENTO, “Direitos fundamentais...”, p. 53.

${ }^{71}$ BODIN DE MORAES, Maria Celina. Danos à pessoa humana: uma leitura Civil-Constitucional dos danos morais. Rio de Janeiro/São Paulo: Renovar, 2003, p. 109.

${ }^{72} \mathrm{O}$ princípio da solidariedade também aparece consubstanciado no Preâmbulo da Constituição Federal ao estabelecer que os direitos sociais e individuais, a liberdade, a segurança, o bem-estar, o desenvolvimento, a igualdade e a justiça como valores supremos de uma sociedade fraterna. À vista de tal contexto, merece registro as linhas traçadas por SILVA ao comentar o objetivo constitucional de estabelecer uma "sociedade livre, justa e solidária” (art. $3^{\circ}$, I,), onde o constitucionalista refere que tal missão constitucional posta no âmbito da República Federativa brasileira implica a construção de uma "ordem de homens livres, em que a justiça distributiva e retributiva seja um fator de dignificação da pessoa e em que o sentimento de responsabilidade e apoio recíprocos solidifique a idéia de comunidade fundada no bem comum. Surge aí o signo do Estado Democrático de Direito, voltado à realização da justiça social, tanto quanto a fórmula liberdade, igualdade e fraternidade o fora no Estado Liberal proveniente da Revolução Francesa”. SILVA, José Afonso da. Comentário contextual à Constituição. 2.ed. São Paulo: Malheiros, 2006, pp. 46-47.
} 
solidariedade”. ${ }^{73}$ Deve-se referir o necessário resguardo do núcleo essencial dos direitos (e princípios) em colisão, procedendo-se, à luz do caso concreto, sempre com o "teste" da proporcionalidade (adequação, necessidade e proporcionalidade em sentido estrito ou razoabilidade) para traçar a legitimidade constitucional de qualquer medida restritiva de direitos fundamentais. ${ }^{74}$

A solidariedade expressa a necessidade fundamental de coexistência do ser humano em um corpo social, formatando a teia de relações intersubjetivas e sociais que se traçam no espaço da comunidade estatal. Só que aqui, para além de uma obrigação ou dever unicamente moral de solidariedade, há que se transpor para o plano jurídico-normativo tal compreensão, como pilar fundamental à construção de uma sociedade e de um Estado de Direito guardiões dos direitos fundamentais de todos os seus integrantes, sem exclusões. Nesse ponto, concorda-se com BODIN DE MORAES, no sentido de ressaltar a força normativa do agora princípio constitucional da solidariedade, o qual transcende do campo da moral para o mundo jurídico-normativo, uma vez que, como refere a autora, a solidariedade social, no âmbito da "juridicizada sociedade contemporânea”, já não pode ser considerada como resultante de ações eventuais, éticas ou caridosas, pois se tornou um princípio geral do ordenamento jurídico, dotado de força normativa e capaz de tutelar o devido respeito a cada um. ${ }^{75}$ Por fim, a eminente jurista destaca que as hipóteses mais conhecidas e tuteladas com base no fundamento da solidariedade são representadas pela defesa dos consumidores e do meio ambiente. ${ }^{76}$

O princípio da solidariedade não opera de forma isolada no sistema normativo, mas atua juntamente com outros princípios e valores presentes na ordem jurídica, merecendo destaque especial para a justiça social (como justiça distributiva e corretiva), a igualdade substancial e a dignidade humana. Nesse sentido, em que pese a análise voltada mais para o âmbito do direito tributário, é oportuna a lição de TORRES, para quem a solidariedade se aproxima da justiça "por criar o vínculo de apoio mútuo entre os que participam dos grupos beneficiários da redistribuição de bens sociais”, já que a justiça social e a justiça distributiva passam pelo fortalecimento da solidariedade. Assim, assevera o autor que os direitos sociais, ou de segunda dimensão como preferem outros, dependem dos vínculos de fraternidade. ${ }^{77} \mathrm{O}$ mesmo raciocínio pode ser ampliado também para a compreensão dos direitos fundamentais de terceira dimensão, como é o caso dos direitos ecológicos, que, em vista da sua natureza difusa e dispersa em toda a coletividade, também encontram o seu fundamento no princípio da solidariedade e da idéia de justiça ambiental (ou socioambiental). Na perspectiva ecológica, há também a necessidade de se colocar uma redistribuição justa e equânime do acesso aos recursos naturais.

${ }^{73}$ BODIN DE MORAES, “Danos à pessoa humana...”, p. 108.

${ }^{74}$ Quanto aos exames ou testes inerentes à proporcionalidade, em que pese o nosso entendimento contrário à adoção da proporcionalidade como postulado normativo defendido pelo autor ora citado, e sim como princípio constitucional, cfr. ÁVILA, Humberto. Teoria dos Princípios: da definição à aplicação dos princípios jurídicos. 5.ed. São Paulo: Malheiros, 2006, pp. 152-161.

${ }^{75}$ BODIN DE MORAES, “Danos à pessoa humana...”, pp. 115-116.

${ }^{76}$ BODIN DE MORAES, “Danos à pessoa humana...”, p. 117.

77 TORRES, “Tratado de Direito...”, p. 183. 
Para destacar a importância do princípio da solidariedade associado à dignidade humana, merece destaque a lição de PERLINGIERI no sentido de que o princípio da solidariedade, juntamente com o princípio da igualdade, é instrumento e resultado da atuação da dignidade social do cidadão, a qual confere a cada um o direito ao “respeito" inerente à qualidade de homem, assim como a pretensão de ser colocado em condições idôneas de exercer as próprias aptidões pessoais, assumindo a posição a estas correspondentes. ${ }^{78}$ Na mesma perspectiva, BODIN DE MORAES destaca que a solidariedade foi consagrada no âmbito constitucional como princípio geral, que tem como objetivo, à luz do que foi acima exposto, a "igual dignidade social”, garantindo uma existência humana digna e saudável comum a todos os membros da sociedade. ${ }^{79}$

ANTUNES ROCHA, por sua vez, reforça com precisão a relação direta entre solidariedade e dignidade humana, contemplados pelos sistemas constitucionais contemporâneos, relatando uma nova face da "tortura" no contexto brasileiro hodierno como subproduto da "falta" de solidariedade no universo social, qual seja: a fome. A Ministra do Supremo Tribunal Federal destaca que, da mesma forma que a tortura individualizada, aquela praticada de maneira direta e específica num atentado contra o corpo da pessoa, pelo que impõe solução identicamente objetivada e dirigida à pessoa do torturador,

a fome toma a forma de uma tortura que se impõe socialmente, atingindo grupos e decorrendo da adoção de políticas públicas ou de decisões econômicas (ou ambas) que agridem pessoas que se espalham e se escondem, conquanto sejam visíveis como sombras sociais que perambulam pelas praças públicas $e$ habitam viadutos imundos. ${ }^{80}$

Na mesma perspectiva do quadro social descrito acima, tem-se como um dos elementos mais marcantes consubstanciados no princípio da solidariedade justamente à idéia de justiça distributiva (e também corretiva), já que o princípio oxigena a relação entre sociedade e Estado, deslocando parte das responsabilidades e encargos sociais para os particulares, principalmente no que tange à concretização dos direitos fundamentais e da dignidade humana, o que, especialmente no modelo liberal, só era possível de se conceber em face do Estado. MATEO também destaca a exigência de justiça distributiva contida no princípio da solidariedade, referindo-se, inclusive, à idéia de "círculos sociais progressivamente ampliados", o que objetiva contemplar uma dupla dimensão intercomunitaria e intergeneracional para a aplicação do princípio. $^{81}$

${ }^{78}$ PERLINGIERI, Pietro. Perfis do Direito Civil: introdução ao Direito Civil Constitucional. Tradução de Maria Cristina De Cicco. Rio de Janeiro: Renovar, 1999, p. 37.

${ }^{79}$ BODIN DE MORAES, “Danos à pessoa humana...”, p. 114.

${ }^{80}$ ROCHA, Cármen Lúcia Antunes. "Vida Digna: Direitos, Ética e Ciência”. In: ROCHA, Cármen Lúcia Antunes (Coord.). O Direito à Vida Digna. Belo Horizonte: Editora Fórum, 2004, p. 76.

81 "Este principio tiene intrínseca validez y operatividad por lo que debería razonablemente esperarse su efectividad en círculos sociales progresivamente ampliados. Su transcendencia para la tutela del ambiente opera en una doble dimensión: intercomunitaria e intergeneracional. La importancia de la aplicación de este principio para la efectividad de la tutela ambiental se deriva de las propias exigencias de la justicia distributiva, lo que es válido tanto a escala extra como intracomunitária y nacional”. MATEO, "Manual de Derecho Ambiental...”, p. 44. 
O Princípio 3 da Declaração do Rio, no mesmo sentido, conforma a idéia de um desenvolvimento sustentável que atenda, de forma eqüitativa as necessidades em termos econômicos, sociais e ambientais das gerações humanas presentes e futuras. ${ }^{82}$ Também o conceito de desenvolvimento sustentável trazido pelo Relatório Nosso Futuro Comum da Comissão Mundial sobre Meio Ambiente e Desenvolvimento traz a idéia de que há que se atender às necessidades das gerações presentes, mas sem comprometer a possibilidade de as gerações futuras atenderem a suas próprias necessidades. ${ }^{83} \mathrm{O}$ princípio da solidariedade encontra-se necessariamente consubstanciado no conceito de desenvolvimento sustentável. A própria natureza difusa do bem ambiental coloca tal feição à titularidade do direito, que, em regra, deve ser usufruído tendo em vista o interesse de toda a coletividade. Não é a toa que a idéia de um patrimônio comum da humanidade também toca de forma direta a questão ambiental, pois se busca dar a dimensão de importância dos bens ambientais de forma alijada de uma perspectiva individualista.

O comando constitucional expresso no art. 225, caput, tem especial relevância para tal compreensão, pois traz justamente a idéia de responsabilidades e encargos ambientais compartilhados entre Estado e sociedade, quando subscreve que se impõe "ao Poder Público e à coletividade o dever" de defender e proteger o ambiente para as presentes e futuras gerações, destacando que os deveres de solidariedade na tutela ambiental, para além do Estado, são atribuídos agora também aos particulares. A idéia de "dever fundamental” é um dos aspectos normativos mais importantes trazidos pela nova "dogmática” dos direitos fundamentais, vinculando-se diretamente com o princípio da solidariedade. Como bem observa HÄBERLE, a fraternidade ou solidariedade, como o terceiro ideal freqüentemente esquecido da Revolução Francesa, reclama por deveres fundamentais e vinculação social. ${ }^{84}$

\subsection{Solidariedade entre cidadãos de diferentes Estados nacionais}

O princípio da solidariedade deve ser projetado para além das fronteiras dos Estados nacionais, o que se impõe pelo próprio contexto internacional da maioria dos sistemas naturais, no sentido de ser tomado como um imperativo, ao mesmo tempo ético e prático, a conformar e limitar as práticas sociais (e também estatais) predatórias do ambiente, em vista de um desenvolvimento sustentável mundial. O modelo clássico de soberania nacional está com os dias contados em razão da crise ecológica. Nesse sentido, MATEO destaca que

Más allá de los limites que acotan las soberanías de los Estados nacionales, la solidariedad debe ser un imperativo no sólo ético, sino también práctico, impuesto por la base internacional de la mayoría de los sistemas naturales y por la necesidad de limitar, en aras del desarrollo sostenible, un excesivo uso de los recursos, lo que requiere obligadamente de asistencias y transvases.

82 "Princípio 3. O direito ao desenvolvimento deve ser exercido de modo a permitir que sejam atendidas eqüitativamente as necessidades de desenvolvimento e de meio ambiente das gerações presentes e futuras”.

${ }^{83}$ Comissão Mundial sobre Meio Ambiente e Desenvolvimento da ONU. NOSSO FUTURO COMUM/COMISSÃO MUNDIAL SOBRE MEIO AMBIENTE E DESENVOLVIMENTO. 2.ed. Rio de Janeiro: Editora Fundação Getúlio Vargas, 1991, p. 46.

${ }^{84}$ HÄBERLE, “Libertad, Igualdad, Fraternidad...”, p. 52. 
Así la solidariedad aparece como complemento y a la vez consecuencia y corolario de la puesta en vigor de los principios antes enunciados (ubicuidad, sostenibilidad, globalidad y subsidiaridad). ${ }^{85}$

De igual modo, FERRAJOLI registra que o fim dos blocos e, ao mesmo tempo, a crescente interdependência econômica, política, ecológica e cultural realmente transformam o mundo, apesar do aumento de sua complexidade e de seus inúmeros conflitos e desequilíbrios, numa aldeia global. ${ }^{86}$ Deve-se conceber, portanto, o mundo inteiro como integrante de uma mesma "aldeia global" em termos ecológicos. Em outras palavras, pode-se dizer que todos somos reféns, em maior ou menor medida, das condições ambientais, na medida em que a própria teia da vida formulada por CAPRA ${ }^{87}$ determina a conexão entre todos os ecossistemas mundiais. Tal conexão natural entre todos os cantos do mundo é determinante para a idéia de solidariedade entre cidadãos de diferentes nações, pois suas ações prejudiciais ao ambiente trarão efeitos para além das fronteiras dos seus próprios países. O aquecimento global é o exemplo mais ilustrativo de tal situação.

Com base na Convenção sobre Diversidade Biológica (1992) ${ }^{88}$, COMPARATO aponta para a aplicação do princípio fundamental da solidariedade na esfera planetária, destacando a incidência do princípio nas relações entre todas as nações, povos e grupos humanos da mesma geração, bem como entre a geração atual e futura. O autor destaca, como projeção normativa do princípio da solidariedade, o dever fundamental atribuído às presentes gerações de garantir uma qualidade de vida ao menos igual a que desfrutam no presente para as futuras gerações. ${ }^{89}$ Aí está um dos aspectos mais importantes do princípio da solidariedade, que, em face de conter a liberdade individual naquilo em que ela represente uma ameaça ao desfrute dos direitos fundamentais e, principalmente, da dignidade humana dos indivíduos, busca equilibrar as relações sociais na esfera comunitária mundial, estabelecendo uma carga de responsabilidades e deveres (que outrora só tocava ao Estado) aos particulares tanto no plano interno dos Estados nacionais quanto no plano internacional.

\subsection{Solidariedade entre diferentes gerações humanas}

Como já referido anteriormente, outro aspecto fundamental por trás do princípio

${ }^{85}$ MATEO, “Manual de Derecho Ambiental...”, p. 44.

${ }^{86}$ FERRAJOLI, “A soberania no mundo...”, pp. 46-47.

${ }^{87}$ CAPRA, Fritjof. A teia da vida: uma nova compreensão científica dos sistemas vivos. São Paulo: Cultrix, 1996.

${ }^{88}$ A Convenção sobre a Diversidade Biológica foi aprovada pelo Decreto Legislativo n. 2, de 03.02.1994, e promulgada pelo Decreto n ${ }^{\circ}$ 2.519, de 16.03.1998, incorporando-se ao ordenamento jurídico brasileiro.

${ }_{89}^{89}$ "Ela regula o direito da humanidade à preservação da biosfera, ou seja, a harmonia ambiental do planeta. Trata-se de aplicar, na esfera planetária, o princípio fundamental da solidariedade, tanto na dimensão presente quanto na futura, isto é, solidariedade entre todas as nações, povos e grupos humanos da mesma geração, bem como solidariedade entre a geração atual e as futuras. É evidente que a geração presente tem o dever fundamental de garantir às futuras gerações uma qualidade de vida pelo menos igual à que ela desfruta atualmente. Mas não é menos evidente que esse dever para com as gerações pósteras seria despido de sentido se não se cuidasse de superar, desde agora, as atuais condições de degradação ambiental em todo o planeta, degradação essa que acaba por prejudicar mais intensamente as massas miseráveis dos países subdesenvolvidos”. COMPARATO, Fábio Konder. A afirmação histórica dos direitos humanos. 3.ed. São Paulo: Saraiva, 2003, p. 422. 
constitucional da solidariedade, especialmente na sua aplicação voltada para a questão ambiental, diz respeito à solidariedade entre as gerações humanas presentes (ou viventes) e as gerações humanas futuras, à luz, inclusive, do reconhecimento da dignidade de tais vidas potenciais. Tal situação se dá em razão de que a proteção ambiental, como refere o próprio caput (parte final) do art. 225 da Constituição Federal, objetiva garantir condições ambientais favoráveis ao desenvolvimento da vida humana em patamares de dignidade não apenas para as gerações que hoje habitam a Terra e usufruem dos recursos naturais, mas salvaguardando tais condições também para as gerações que irão habitar a Terra no futuro, o que implica, necessariamente, um conjunto de deveres e responsabilidades a cargo das gerações presentes para com as gerações futuras. Nesse sentido, OST coloca o questionamento a respeito do reconhecimento de um dever (das gerações presentes) de assegurar a existência das gerações futuras..$^{90}$

Ao formular o princípio de eqüidade intergeracional, SAMPAIO destaca que "as presentes gerações não podem deixar para as futuras gerações uma herança de déficits ambientais ou do estoque de recursos e benefícios inferiores aos que receberam das gerações passadas. Esse é um princípio de justiça ou eqüidade que nos obriga a simular um diálogo com nossos filhos e netos na hora de tomar uma decisão que lhes possa prejudicar seriamente". ${ }^{11}$ Há um princípio de justiça ou equidade intergeracional que também fortalece tal entendimento. ${ }^{92} \mathrm{Na}$ medida em que o vínculo existencial entre o ser humano e as condições naturais para o seu desenvolvimento é cada vez mais reforçado no âmbito científico (e repercute nas formulações políticas e jurídicas), é possível, como um critério de justiça ou equidade, cogitar inclusive de um "direito" das futuras gerações a não receberem a Terra ou os recursos naturais em condições ambientais piores do que as recebidas pelas gerações anteriores, a conformar, inclusive, uma proibição de retrocesso em termos de qualidade ambiental. À luz da responsabilidade (e também cautela) imposta como imperativo à conduta do ser humano contemporâneo, especialmente quando do manuseio de novas tecnologias, o princípio da precaução joga um papel fundamental para a tutela dos interesses (ou direitos?) das gerações futuras. ${ }^{93}$

${ }^{90}$ OST, François. A natureza à margem da lei (a ecologia à prova do direito). Lisboa: Instituto Piaget, 1995, p. 318.

${ }^{91}$ SAMPAIO, José Adércio Leite. “Constituição e meio ambiente na perspectiva do direito constitucional comparado”. In: SAMPAIO, José Adércio Leite; WOLD, Chris; NARDY, Afrânio. Princípios de Direito Ambiental na dimensão internacional e comparada. Belo Horizonte: Del Rey, 2003, p. 53.

92 A idéia de justiça entre gerações também está presente na formulação de RAWLS acerca do "princípio da poupança justa”, concebendo também a existência de deveres e obrigações entre gerações. "Podemos agora ver que as pessoas de diferentes gerações têm deveres e obrigações em relação umas às outras exatamente como as têm as pessoas que vivem numa mesma época. A geração atual não pode fazer o que bem entender, mas é obrigada, por princípios que seriam escolhidos na posição original, a definir a justiça entre as pessoas que vivem em épocas diferentes. Além disso, os homens têm um dever natural de defender e promover o crescimento das instituições justas, e para isso a melhoria da civilização até um certo nível é exigida. A dedução desses deveres e obrigações pode parecer no início uma aplicação forçada da doutrina contratualista. No entanto, essas exigências seriam reconhecidas na posição original e, por isso, a concepção da justiça como eqüidade abrange essas questões sem nenhuma alteração de sua idéia básica”. RAWLS, John. Uma teoria da justiça. 2.ed. Tradução de Almiro Pisetta e Lenita Maria Rímoli Esteves. São Paulo: Martins Fontes, 2002, pp. 323-324.

${ }^{93}$ Nesse sentido, cfr. o artigo de KISS, Alexandre. "Os direitos e interesses das futuras gerações e o princípio da precaução”. In: VARELLA, Marcelo Dias; PLATIAU, Ana Flávia Barros (Orgs.). Princípio da Precaução. Belo Horizonte: Del Rey, 2004, pp. 1-12. 
Portanto, a incidência normativa do princípio da solidariedade nas relações entre gerações humanas revela a carga de deveres atribuída à geração presente, reforçando, inclusive a tese da dignidade de tais vidas futuras, conforme já sinalizado em tópico anterior.

\subsection{Solidariedade entre espécies naturais}

Como projeção normativa do princípio constitucional da solidariedade na órbita ecológica, como refere BECK, há que se conceber também uma "solidariedade entre todas as coisas vivas”, na forma de uma comunidade entre a terra, as plantas, os animais e os seres humanos, tendo em vista que a ameaça ecológica afeta por igual a todos e ao todo. ${ }^{94}$ A proposta formulada pelo sociólogo alemão não se distancia do contrato natural de SERRES, já que também transporta o ideal de uma comunidade política integrada por todos os membros da comunidade natural, considerando o respeito e a reciprocidade que deve orientar as relações estabelecidas em tal quadrante comunitário. A consciência de uma solidariedade entre os seres naturais é despertada, conforme acentua BECK, em razão de as ameaças à vida ocasionadas pelo desenvolvimento civilizatório fazerem com que o ser humano se reconheça como um ser natural integrante de um todo natural ameaçado, e ao mesmo tempo responsável por tal situação de ameaça existencial. A ameaça de contaminação faz com que o ser humano perceba que o seu corpo forma parte das "coisas naturais", e que, portanto, juntamente com as pedras e as árvores, está também exposto à chuva ácida. ${ }^{95}$ Tal consciência leva o ser humano a reconhecer uma comunidade natural, frente a qual uma relação de solidariedade e respeito mútuo apresenta-se como pressuposto para a permanência existencial das espécies naturais (incluída entre eles a espécie humana).

A idéia de "solidariedade entre espécies naturais" transporta o reconhecimento do valor intrínseco inerente a todas as manifestações existenciais, bem como o respeito e a reciprocidade indispensável ao convívio harmonioso entre todos os seres vivos na nossa casa planetária comum. E, para tanto, é pertinente a proposta de um contrato natural formulada por SERRES ${ }^{96}$, capaz de ampliar o atual pacto social, incluindo novos parceiros de aventura natural no rol dos sujeitos de direito. A proteção ambiental passa a ser uma das bases-éticas fundamentais da sociedade contemporânea na sua caminhada civilizatória, exigindo-se, para o convívio harmonioso entre todos os integrantes da comunidade humana, a firmação de um pacto socioambiental em relação à proteção da Terra, onde todos os atores sociais e estatais assumam as suas responsabilidades e papéis na construção de uma sociedade nacional e mundial ambientalmente saudável. Propõe-se uma reconciliação do homem natural com o homem político.

\section{CONCLUSÕES ARTICULADAS}

1. A adoção do marco jurídico-constitucional socioambiental resulta da convergência necessária dos direitos sociais e os direitos ambientais num mesmo projeto jurídico-político para o desenvolvimento humano. O enfrentamento dos problemas ambientais e a opção por um desenvolvimento sustentável passam necessariamente

${ }^{94}$ BECK, “La sociedad del riesgo...”, p. 83.

${ }^{95}$ BECK, “La sociedad del riesgo...,", p. 83.

${ }^{96}$ SERRES, Michel. O contrato natural. Tradução de Serafim Ferreira. Lisboa: Instituto Piaget, 1990. 
pela correção do quadro alarmante de desigualdade social e da falta de acesso aos direitos sociais básicos, o que, diga-se de passagem, também é causa potencializadora da degradação ambiental.

2. O Estado Socioambiental de Direito atua no sentido de combater a hipertrofia do indivíduo e a base axiológica marcadamente patrimonialista do modelo do Estado Liberal, projetando como seu estandarte axiológico o terceiro (e quase esquecido) lema da Revolução Francesa, qual seja, a solidariedade (ou fraternidade), de cunho eminentemente existencial, comunitário e universalista.

3. O modelo de Estado Socioambiental agrega as conquistas positivas (em termos de tutela da dignidade humana) dos modelos de Estado de Direito que o antecederam, incorporando a tutela dos novos direitos transindividuais e, num paradigma de solidariedade humana, projetando a comunidade humana num patamar mais evoluído de efetivação de direitos fundamentais (especialmente dos novos direitos de terceira dimensão, como é caso da proteção ambiental).

4. Deve-se transcender de um pacto social para um pacto socioambiental, em vista de contemplar o novo papel do Estado e da sociedade no âmbito do Estado Socioambiental de Direito. O comando constitucional expresso no art. 225, caput, traz justamente a idéia de responsabilidades e encargos ambientais compartilhados entre Estado e sociedade, quando subscreve que se impõe "ao Poder Público e à coletividade o dever" de defender e proteger o ambiente para as presentes e futuras gerações. Os deveres de solidariedade no âmbito da tutela ambiental são atribuídos agora, para além do Estado, também aos particulares.

5. A idéia de "dever fundamental” é um dos aspectos normativos mais importantes trazidos pela nova "dogmática” dos direitos fundamentais, vinculando-se diretamente com o princípio da solidariedade. Para além de uma obrigação ou dever unicamente moral de solidariedade, há que se trazer para o plano jurídico-normativo tal compreensão, como pilar fundamental à construção de uma sociedade e de um Estado de Direito guardiões dos direitos fundamentais (de todas as dimensões) de todos os seus integrantes, e mesmo dos direitos das gerações futuras. 